\title{
Congenital Arthrogryposis and Bilateral Shoulder Flexion in Murrah Buffalo Calf: A Case Report
}

\author{
A. K. Ahuja*, H. Singh, M. Honparkhe and S. Singhal \\ Department of Veterinary Gynaecology and Obstetrics, College of Veterinary Science, Guru \\ Angad Dev Veterinary and Animal Sciences University, Ludhiana, Punjab-141004, India \\ *Corresponding author
}

A B S T R A C T

\begin{tabular}{|c|c|}
\hline Keywords & \\
\hline $\begin{array}{l}\text { Arthrogryposis, } \\
\text { Congenital, } \\
\text { Shoulder flexion, } \\
\text { Calf. }\end{array}$ & \multirow{3}{*}{$\begin{array}{l}\text { Arthrogryposis is a common inherited deformity characterized by } \\
\text { contracture of tendons and fixation of joints. In the present case, a } \\
\text { pluriparous buffalo was presented in the clinics with the history of straining } \\
\text { from } 12 \text { hours. After performing the caesarean section, a dead male buffalo } \\
\text { calf was delivered with bilateral arthrogryposis of carpel joint and fetlock } \\
\text { joint in both the forelimb and fetlock joint in both the hind limb, }\end{array}$} \\
\hline Article Info & \\
\hline $\begin{array}{l}\text { Accepted: } \\
\text { 19 June } 2017 \\
\text { Available Online: } \\
\text { 10 July } 2017\end{array}$ & \\
\hline
\end{tabular}

\section{Introduction}

Arthrogryposis is a common congenital defect that affects the joints of forelimbs and hind limbs, leading to fixation and immobilisation (Sprake, 2015; Andersson et al., 2008). This abnormality was described more in calves, lambs, piglets and foals and seldom in goats, cats, dogs and human beings (Devi Prasad et al., 2010; Shahrokhi and Gharib, 2011). Various breeds of cattle such as Hereford, Holstein-Friesian, Guernsey, Jersey, Ayshire and Brown Swiss have genetic predisposition to this condition (Hartley et al., 1974; Greene et al., 1973). Arthrogryposis occurs mainly due to an alkaloid toxin that acts on the musculoskeletal system leading to permanent joint contracture in forelimbs and/or hind limbs (Shupe et al., 1967a).
The affected limbs cannot be straightening out (Hartley et al., 1974; Sprake, 2015) and may include incorrect articular arrangement or rotational irregularity. The defect is mostly seen as bilateral in the fore limbs and less often in the hind limbs. With the advancing age of calf the condition of arthrogryposis deteriorates due to secondary effects caused by increased stress of weight gain and increased movement of animal (Keeler et al., 1969; Shupe et al., 1967b).

\section{History and clinical signs}

A Murrah buffalo in its $4^{\text {th }}$ parity was presented to clinics with the history of straining since 12 hours. The animal had surpassed the $1^{\text {st }}$ stage of labour. The clinical 
parameter shows a slight deviation from the normal. Per vaginum exam revealed the foetus in anterior presentation, dorsosacral in position but with bilateral shoulder flexion. No foetal reflex or/ movements were present.
The cervix was relaxed and completely dilated but due to oedema of the canal, space was not adequate for delivery of foetus so the buffalo was put on caesarean section.

Fig.1 Joint fixation at carpel and fetlock joint in forelimb and at fetlock joint in hind limb

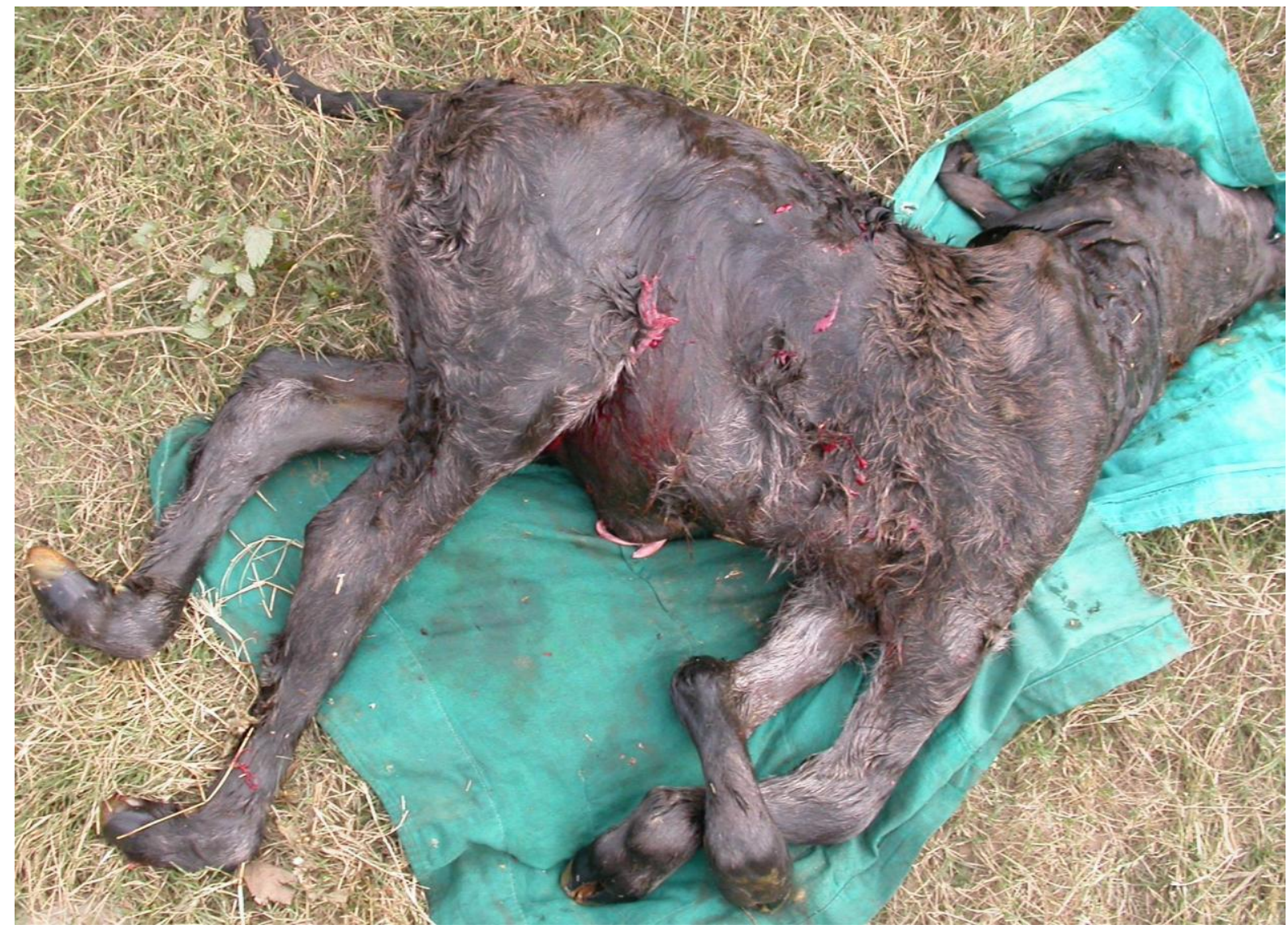

\section{Treatment and Discussion}

The animal was given intravenous fluid, antibiotics and dexamethasone prior to operation. After restraining the buffalo in right lateral recumbency, left paramedianlapro-hysterectomy was performed using local infiltration of $2 \%$ lignocaine, along the incision line (4 inches above parallel to milk vein). The uterus was searched out for a dead abnormal male foetus/ calf. After removing the placental shreds from the uterus, incision was sutured using chromic catgut no. 2 employing double layer of
Cushing's and Lambert pattern. The buffalo was administered intravenous fluid as inj. Dextrose Normal Saline (4 litre) and Normal Saline (5 litres), metrogyl (1.5 litres), Caborogluconate $(450 \mathrm{ml}$, slow $\mathrm{I} / \mathrm{V})$ and antibiotic, antihistaminic and antiinflammatory were administered. Following closure of the surgical wound, the dam was put under antibiotic cover of parenteral and intrauterine antibiotics. Skin sutures were removed after 14 days. The dead male calf was examined carefully and it clearly shows that fixation of carpel joint and fetlock joint in both the forelimb and fetlock joint in both the 
hind limb, respectively (Fig. 1). The internal organs of calf were normal. In most of the cases the aetiology behind the arthrogryposis remains unknown, but the most accepted theory is the decreased limb movements of the foetus in uterus (Radostits et al., 2007). Arthrogryposis is the stiffness or limited movements of one or more joints and change of posture and limb function due to permanent contracture of joints at birth (Doherty et al., 2000). The extent of this malformation is variable and may affect only one, two, or four legs and the axial skeleton (Van Vleet, 2007). Arthrogryposis usually affects the fore and hind limbs and the distal joints (Belli, 2007).

\section{References}

Anderson, D. E., Desrochers, A. and St Jean, G. 2008. Management of tendon disorders in cattle. The Veterinary Clinics of North America. Food Animal Practice, 24(3): 551-566.

Belli, C.B., Molina, L.R.P. and Netto, D.M. 2007. A case report of arthrogrypos is in caprine. Ars. Vet. Jab. SP., 23: 67-70.

Devi Prasad, V., Hari Krishna, N.V.V., Sreenu, M. and Thangadurai, R. 2010. Arthrogryposis in a calf. Vet.World. 3: 335-336.

Doherty, M.L., Kelley, E.P., Healy, A.M., Callanan, J.J., Crosby, T.F., Skelly, C. and Boland, M.P. 2000.Congenital arthrogryposis: an inherited limb deformity in pedigree Suffolk lambs. Vet. Rec., 146: 748-753.
Greene, H. J., Leipold, H. W., Huston, K. and Guffy, M. M. 1973a. Bovine congenital defects: arthrogryposis and associated defects in calves. American Journal of Veterinary Research, 34(7):887-891.

Hartley, W. J. and Wanner, R. A. 1974. Bovine congenital arthrogryposis in New South Wales. Australian Veterinary Journal, 50(5): 185-188.

Radostits, O.M., Gay, C.C., Hinchcliff, K.W. and Constable, P.D. 2007. Veterinary medicine. 10th Edn. Elsevier Science Health Science Division. pp: 1962-1978.

Shahrokhi, A. and Gharib, M. 2011. A case report of bilateral upper extremities arthrogryposis. Ir. Reh. J., 9: 75- 77.

Shupe, J. L., Binns, W., James, L. F. and Keeler, R. F. 1967a. Lupine, a cause of crooked calf disease. Journal of the American Veterinary Medical Association, 151(2): 198-203.

Shupe, J. L., James, L. F. and Binnis, W. 1967b. Observations on crooked calf disease. Journal of the American Veterinary Medical Association, 151(2): 191-197.

Sprake, P. 2015. Diseases of the bones, joints and connective tissues. In: Smith, B.P. (ed), Large Animal Internal Medicine. St. Louis: Elsevier Mosby, pp. 1106.

Van Vleet, J.F. and Valentine, B.A. 2007. Muscle and tendon. In: Jubb, KVF; Kennedy, PC and Palmer, N (Eds.), Pathology of domestic animals. (5th Edn.), Vol. 1, University of Chicago, Elsevier Saunders, Academic Press Inc., pp: 204-206.

\section{How to cite this article:}

Ahuja, A.K., H. Singh, M. Honparkhe and Singhal, S. 2017. Congenital Arthrogryposis and Bilateral Shoulder Flexion in Murrah Buffalo Calf: A Case Report. Int.J.Curr.Microbiol.App.Sci. 6(7): xx-Xx. doi: $\underline{\text { https://doi.org/10.20546/ijcmas.2017.607.181 }}$ 